\title{
Article \\ Financial Development, Saving Rates, and International Economic Volatility: A Simple Model
}

\author{
Hejie Zhang ${ }^{1}$, Huiming $\mathrm{Lv}^{2}$ and Shenghau $\operatorname{Lin}^{3, *(D)}$ \\ 1 School of Economics and Management, Zhejiang Sci-Tech University, Hangzhou 310018, China; \\ zhanghejie@zstu.edu.cn \\ 2 Business School, Ningbo University, Ningbo 315211, China; lvhuiming@nbu.edu.cn \\ 3 Department of Public Administration, Law School, Ningbo University, Ningbo 315211, China \\ * Correspondence: shenghauhlin@nbu.edu.cn; Tel.: +86-13-7706-22597
}

Citation: Zhang, H.; Lv, H.; Lin, S. Financial Development, Saving Rates, and International Economic Volatility: A Simple Model. Mathematics 2021, 9, 2010. https://doi.org/10.3390/ math9162010

Academic Editor: Bahram Adrangi

Received: 8 July 2021

Accepted: 18 August 2021

Published: 22 August 2021

Publisher's Note: MDPI stays neutral with regard to jurisdictional claims in published maps and institutional affiliations.

Copyright: (c) 2021 by the authors. Licensee MDPI, Basel, Switzerland. This article is an open access article distributed under the terms and conditions of the Creative Commons Attribution (CC BY) license (https:/ / creativecommons.org/licenses/by/ $4.0 /)$.

\begin{abstract}
This study constructs a dynamic and open economy model to show that low saving rates are the cause of economic volatility in developed countries, whereas inadequate financial development is identified as the reason for economic volatility in emerging countries. With low saving rates or inadequate financial development, countries find it difficult to avoid economic volatility, because it is difficult to alleviate the financing constraints of firms and maintain the stability of investment. Under similar conditions, economic volatility is more severe in developed countries and has spillover effects by triggering interest rate fluctuations in the global capital market and intensifying economic volatility in other countries. By contrast, emerging countries or small economies do not have spillover effects. To avoid dramatic international economic volatility, emerging countries should prompt financial development, and developed countries should increase their saving rates.
\end{abstract}

Keywords: financial development; saving rates; economic volatility

\section{Introduction}

Economic volatility and economic growth are two major research areas in macroeconomics. Several studies have confirmed the impact of saving rates and financial development on economic growth [1,2]. Attributable to the negative relationship between economic growth and economic volatility [3], there are only a few studies on the relationship between saving rates, financial development, and economic volatility [4]. Both savings and financial development achieve economic growth by stimulating investment [1,2], and investment is the most volatile factor in economic volatility [5-7]. Therefore, savings and financial development may affect economic volatility by influencing investment. Figure $1 \mathrm{a}, \mathrm{b}$ show that developed countries have relatively high levels of financial development but low saving rates, whereas emerging countries have high saving rates but low levels of financial development. Hence, we ask the following: What is the impact of lagging financial development on economic volatility in emerging countries? What is the impact of low saving rates on economic volatility in developed countries? What are the impacts of the imbalances between the financial development level and saving rates in developed and emerging countries on international economic volatility? What are the underlying mechanisms that lead to economic volatility? However, research on these topics is lacking. This paper answers these questions through a theoretical model and proposes directions for policy changes based on inferences from the model to alleviate international economic volatility and crises. 


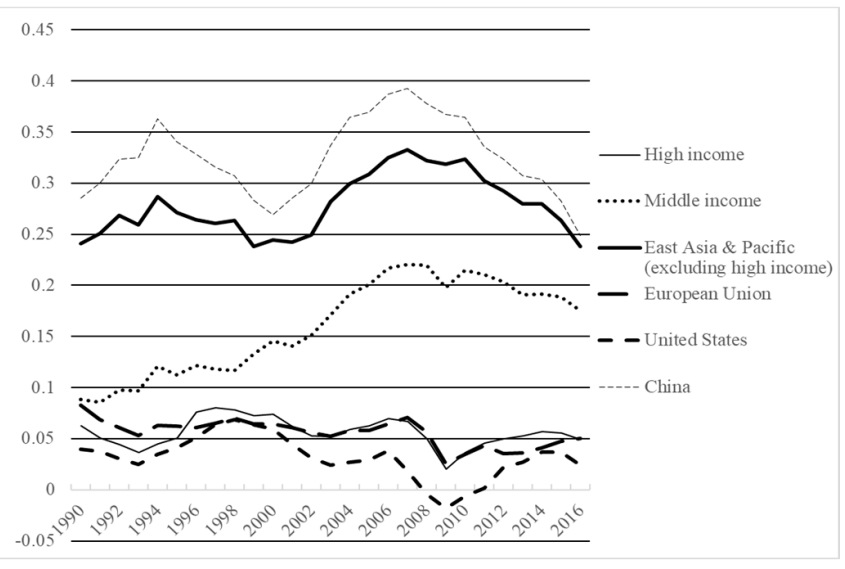

(a)

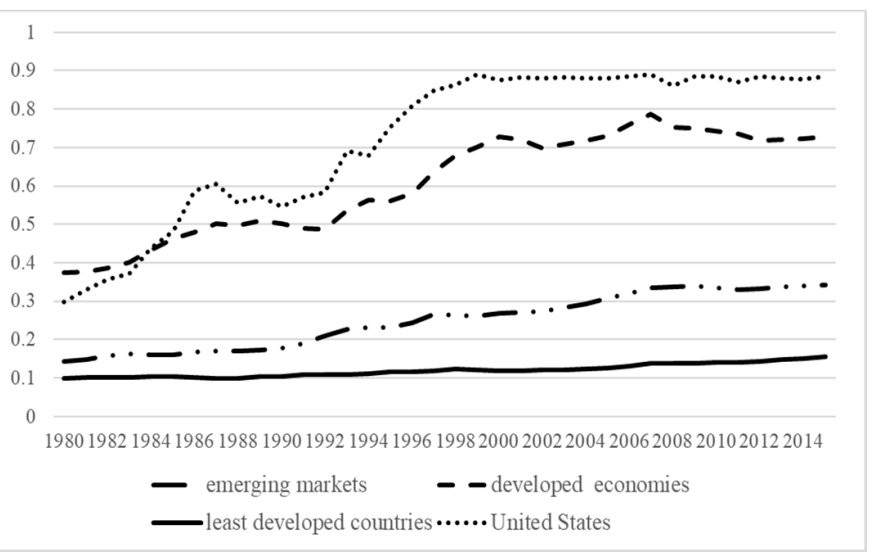

(b)

Figure 1. (a) Net National Savings (\% of gross national income, GNI), sourced by World Development Indicators (WDI); (b) Financial Development Index, data from Svirydzenka [8].

The model concludes that low saving rates are the cause of economic volatility in developed countries while lagging financial development triggers economic volatility in emerging countries. With low saving rates in developed countries and low levels of financial development in emerging countries, it is difficult to ease firms' financing constraints and maintain investment stability, which can cause economic volatility. In addition, the theoretical model concludes that: (1) Under similar conditions, economic volatility is more severe in developed countries - compared to emerging countries-and has spillover effects by triggering interest rate fluctuations in the global capital market and intensifying economic volatility in other countries; however, economic volatility in emerging countries has no spillover effects. (2) House price volatility plays an important role in economic volatility. (3) Pro-cyclical changes in banks' balance sheets have a catalytic role of financial accelerator that increases economic volatility. (4) Countercyclical monetary policies can smooth economic volatility; in particular, if the real interest rates are equal to or less than zero, countries can effectively avert economic recessions and prevent extreme economic volatility by stabilizing and stimulating investment. (5) Technological progress can alleviate economic volatility by increasing the rate of return on investment.

This study makes the following contributions. Unlike a few other studies that highlight the impact of saving rates or financial development on economic volatility, this study emphasizes that only by increasing the level of financial development and saving rates together, both nationally and internationally, can countries effectively avert severe economic volatility. The remainder of the paper is structured as follows. Section 2 presents a review of the relevant literature and analysis mechanism to provide a theoretical basis for the model; Section 3 describes the cyclical characteristics of important economic variables to provide a realistic foundation for the model; Section 4 presents the theoretical model. Section 5 summarizes the paper and discusses the policy implications of the theoretical model.

\section{Literature Review}

Economic volatility is the fluctuations of economic variables (usually measured by the growth rate of GDP) around the long-term trend over time. The expansion of economic activities is followed by economic contraction, which in turn is followed by further economic expansion. Economic volatility can be divided into four stages: recovery, expansion, recession, and depression. Based on the double troughs division method, the interval from the lowest point of one fluctuation to the next lowest point is taken as one cycle. Economic volatility is often accompanied by drastic fluctuations in employment rate, consumption, investment, and capital market [9]; it even causes unrest in countries and the world. Therefore, studying the mechanism underlying the formation of economic 
volatility and proposing effective measures to alleviate drastic economic volatility can be of immense significance.

The explanations of economic volatility come from the business cycle theory. The early business cycle theory believed economic volatility is a response of the economic system to shocks; the economy would eventually move toward a new equilibrium. The Great Depression of the 20th century heralded the failure of the early business cycle theory, and Keynesianism came into being. Relying on the assumption of sticky wage and prices, according to Keynesianism, insufficient effective demand led to the Great Depression. It also stated that the policy of expanding aggregate demand is imperative. However, Keynesianism could not explain the inflation and economic stagnation that led to stagflation in the 1970s. The modern monetary theory closely associated with Friedman and the theory of rational expectations closely associated with Lucas provided new explanations for the business cycle, which led to the proposal of the neoclassical business cycle theory. According to this, once the shocks of aggregate demand are expected by rational agents, the wage and prices will change accordingly. The shocks of aggregate demand have only nominal but no actual effects. Only under the condition of incomplete information do shocks of aggregate demand have real effects. Therefore, economic volatility is mainly caused by the real factors of aggregate supply [10,11]. Kydland and Prescott [12] further regarded technology shock as the main force of economic volatility based on Lucas [11], and thus, the real business cycle theory (RBC) was born. However, the assumption of perfect competition, complete information, and the neglect of money make RBC theory unconvincing. This led to the formation of the new Keynesian business cycle theory. The new Keynesian dynamic stochastic general equilibrium (NK-DSGE) model became the standard paradigm for analyzing economic volatility. According to this theory, economic volatility is caused by shocks of supply and demand together. Further, both monetary policy and fiscal policy have impacts on economic volatility.

All the above theories propose that economic volatility is caused by exogenous shocks. However, in recent years, the endogenous business cycle theory emerged to examine the sources of economic volatility from within the economic system; it proposes that nonlinear and unstable mechanisms (such as firms' investment) are the endogenous driving force of economic volatility. Financial development plays a vital role in firms' investment, and hence, it may have a significant impact on economic volatility. Especially, the 1997 Asian financial crisis and the 2008 global economic recession led to an increasing number of scholars recognizing the role of the financial sector in spreading and amplifying economic shocks that eventually lead to economic volatility and financial crises [13-16]. The main mechanism is that economic shocks decline the net wealth of firms and banks, which makes banks are reluctant to extend credit to firms. Accordingly, firms face financing constraints; consequently, production activities become more difficult, and vicious circles appear eventually, the economic shocks were amplified several times. Therefore, some scholars believe that low levels of financial development amplify economic volatility [5].

However, the above literature only shows that the financial sector has a critical role in extending and amplifying economic shocks, but it does not indicate the impact of financial development on economic volatility. To examine this relationship, we must first understand financial development. Although a broad concept, the basic significance of financial development lies in the strength, efficiency, and stability of finance provided by the financial sector to firms and individuals [8,17-19]. Therefore, when the level of financial development is high, financing constraints are loose, and firms' ability to cope with economic shocks is strong. Thus, a high level of financial development may reduce economic volatility. Some empirical studies use international panel data and the proportion of credit or private credit to GDP to measure the level of financial development and find that financial development helps to reduce consumption volatility, stock market volatility, and output volatility [20-25]. Moreover, this conclusion holds for the United States (US), China, the Organisation for Economic Co-operation and Development (OECD) countries, and other countries $[5,26,27]$. Financial development eases firms' financing constraints 
and stabilizes investment — the most volatile factor in economic volatility-and alleviates economic volatility [5-7].

If financial development helps to mitigate economic volatility, the question arises: why did the 2008 economic recession and the subsequent European debt crisis occur in countries with the highest levels of financial development? Thus, it is evident that financial development is not the only factor that determines financing constraints and investment. Saving rates are another important factor for stabilizing investment flows and the economy. Investment is transformed from savings through financial channels. Financial development determines the efficiency of transforming savings into investment. If saving rates are very low, notwithstanding how adequate financial development may be, it is difficult to stabilize investment and the economy.

Jungeilges and Ryazanova [28] investigated the relationship between national savings and economic volatility through a stochastic Goodwill-type business cycle model and found that an increase in national savings would make the stochastic Goodwill economy more robust, while a decrease in national savings would more likely lead to economic volatility. Figure 2 shows that during the 2008 economic recession and the subsequent European debt crisis, the national saving rates of the US and five European countries continued to decline and plummeted to negative levels, which are historically the lowest. Low saving rates made it difficult for these economies to withstand even a mild economic shock, and economic crises were inevitable.

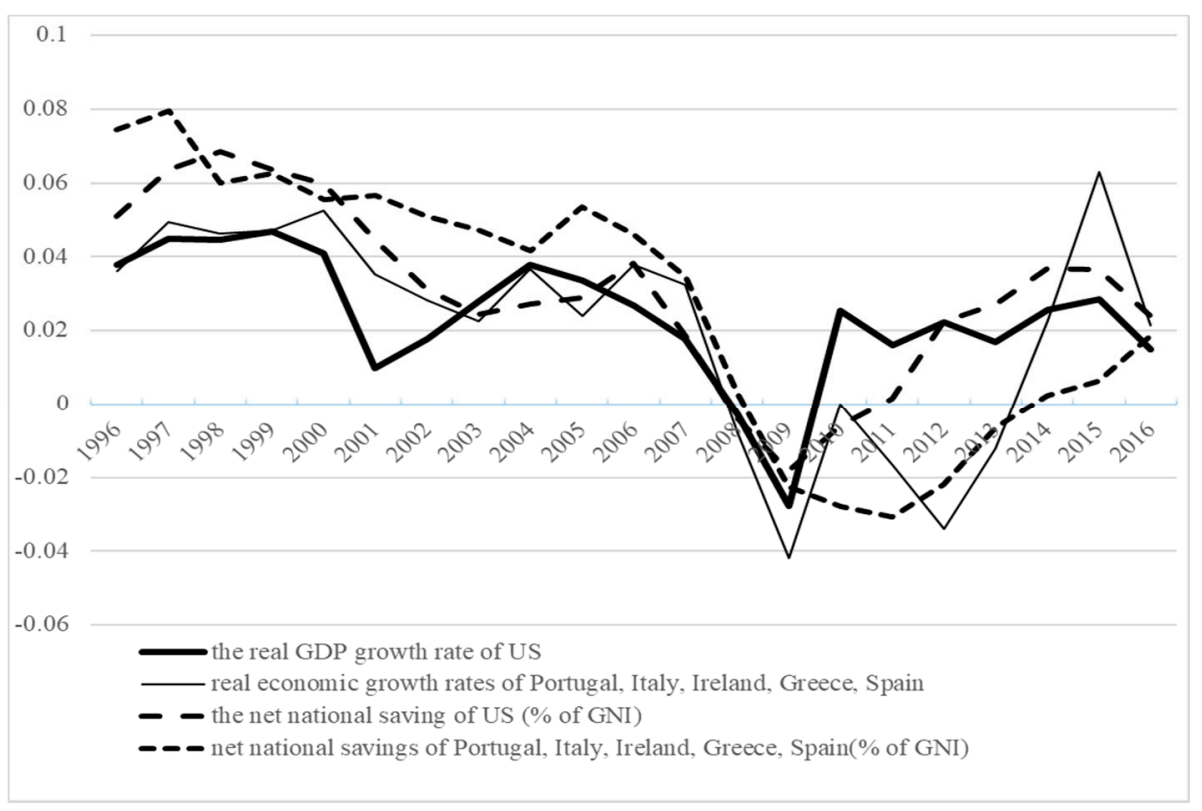

Figure 2. Real Economic Growth Rates and Net National Saving Rates, Data source: WDI(2010=100).

Emerging countries often have very high saving rates but relatively low levels of financial development. These countries cannot convert all savings into investments, nor can they reduce economic volatility by stabilizing firms' investments. Therefore, notwithstanding Southeast Asian countries' positive economic indicators, such as high growth, low inflation, and fiscal balance, the Asian financial crisis broke out in 1997, because financial development had lagged in these countries [18,29].

The existing literature shows that financial development and saving rates have a significant impact on economic volatility. As countries cannot rely only on financial development or saving rates to avoid severe economic volatility, it is necessary to investigate the interactive impact of financial development and saving rates on economic volatility in both developed and emerging countries. Therefore, we raise the following questions: (1) In developed countries, how does the imbalance between low saving rates and high levels of financial development affect economic volatility? (2) Similarly, in emerging countries, 
how does the disparity between high saving rates and low levels of financial development affect economic volatility? Prior literature does not provide any answers to these questions. Although some studies observed the imbalance in global financial development and saving rates, they focused on the impact of global economic imbalances rather than international economic volatility [30-33].

\section{Economic Volatility}

Before constructing the economic volatility model, it is necessary to reveal the cyclical changes in important economic variables. In this study, the theoretical model explains economic volatility only if it captures the characteristics of cyclical changes in the main economic variables. For instance, considering the Asian financial crisis in 1997 and the global economic recession in 2008, this study analyzes the cyclical changes of major economic variables during economic volatility to provide a realistic basis for the theoretical model.

Investment is the most unstable economic variable in economic volatility. Figure $3 a$ shows that the economies of the four Southeast Asian countries, where the Asian financial crisis originated in 1997, suffered a major setback, and investments declined rapidly. However, the crisis did not have a significant impact on the US and other developed countries. Figure 2 shows that the economic growth rates of both the US and a few European countries were still above $4 \%$ in 1997. Figure 3 b shows that investment did not decline in the US, indicating that the spillover effects of economic volatility in small economies are limited. Figure $3 \mathrm{~b}$ shows that when the global economic recession occurred in 2008, investment declined significantly in the US. At the same time, the crisis spread worldwide. Figure 2 shows that the economies of five European countries slipped into a recession; Figure 3a shows that domestic investments diminished in the four Southeast Asian countries, indicating that the economic volatility of developed countries had spillover effects, thereby impacting the economic volatility of emerging countries.

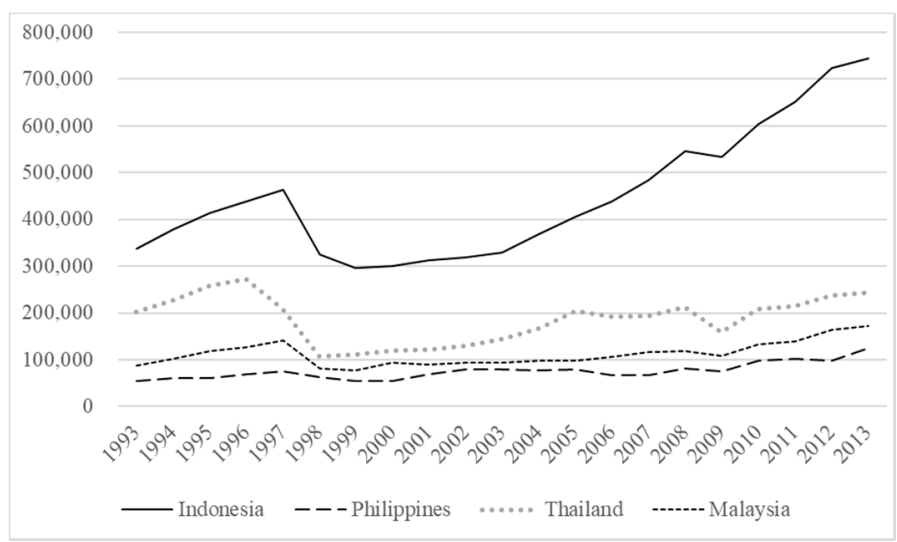

(a)

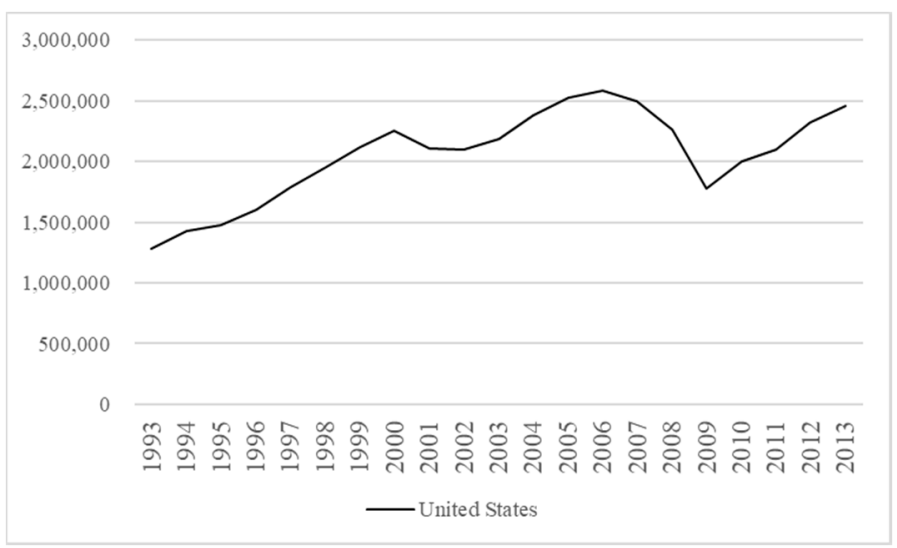

(b)

Figure 3. (a) Real Fixed Asset Investment (Unit: the US \$1 Billion), sourced by Economist Intelligence Unit (EIU) country data; (b) Real Fixed Asset Investment (Unit: the US \$1 Billion), sourced by EIU country data.

The substantial increase or decrease in investment is inseparable from the expansion or contraction of credit $[34,35]$. Figure 4 shows that credit decreased in the Philippines and Thailand after the 1997 financial crisis, especially in Thailand. Similarly, after the 2008 global economic recession, credit declined in the US. 


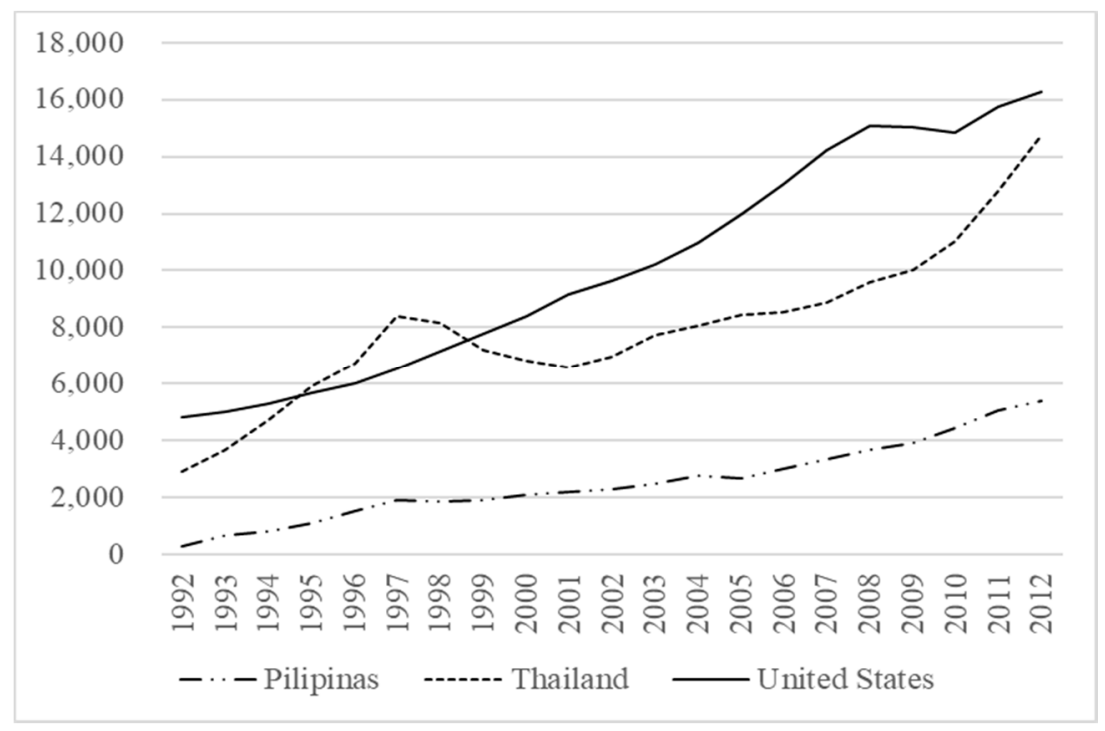

Figure 4. Domestic Loan (Unit: 1 Billion Domestic Currency), sourced by EIU country data.

Substantial increases or decreases of credit and investment often lead to increases or decreases in the prices of factors of production and real interest rates [35]. Figure 5a depicts the trend of the international commodity composite index. Before the economic crisis in 1997, the international commodity composite index had shown an upward trend, but after 1997, the international commodity composite index reached the lowest level. The same thing happened around 2008. When the 2008 economic crisis happened, the international commodity composite index fell precipitously. Figure $5 b$ shows the series of real interest rates in the four Southeast Asian countries and the United States. One can find that before the economic crisis in 1997 and 2008, due to the sharp increase of investment, the demand for credit in these countries had risen, resulting in the rise of real interest rates. When the investment dropped sharply, the real interest rates fell quickly.

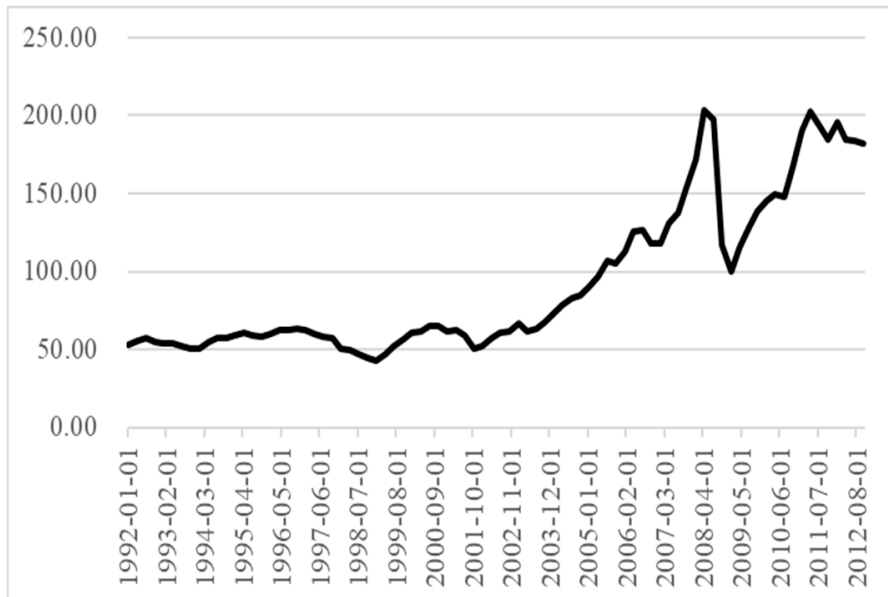

(a)

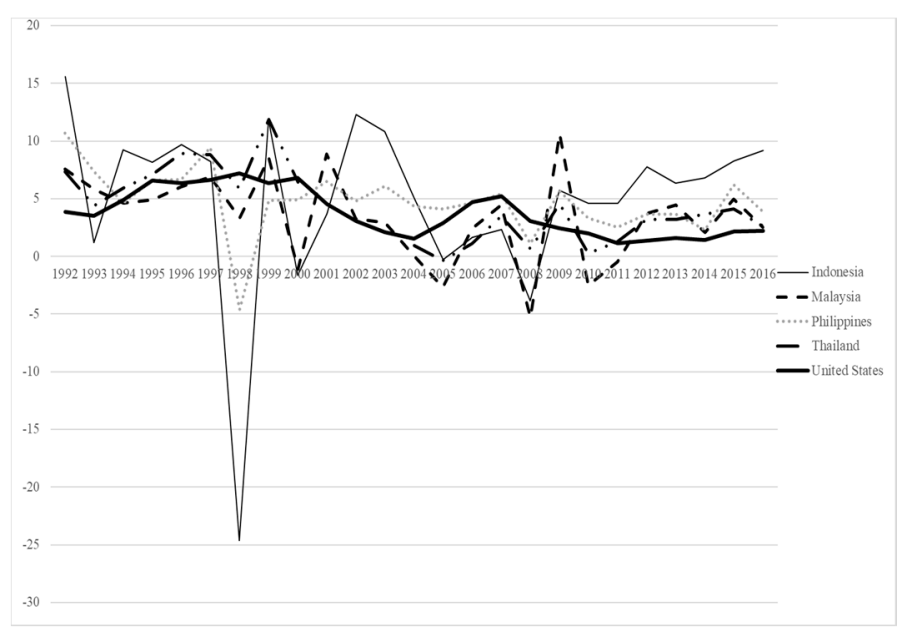

(b)

Figure 5. (a) International Commodity Composite Index, sourced by the Federal Reserve Bank of St.Louis (2005=100); (b) Real Interest Rates (Unit: \%), sourced by WDI.

During an economic crisis, the investments and credit values of firms drop sharply in open economies, and international capital tends to withdraw investment to other countries, causing the devaluation of the exchange rate. Figure 6 reports on the series of non-resident portfolio investments in four Southeast Asian countries and the US, respectively. Inter- 
national capital had flowed into the US and emerging economies before 2008. During the 2008 global economic recession, foreign portfolio investments decreased sharply in these countries.

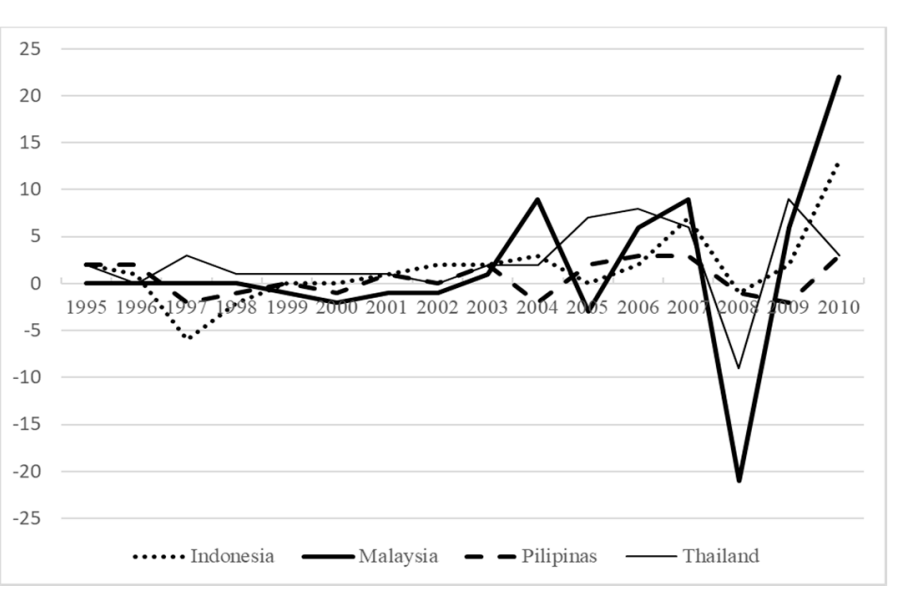

(a)

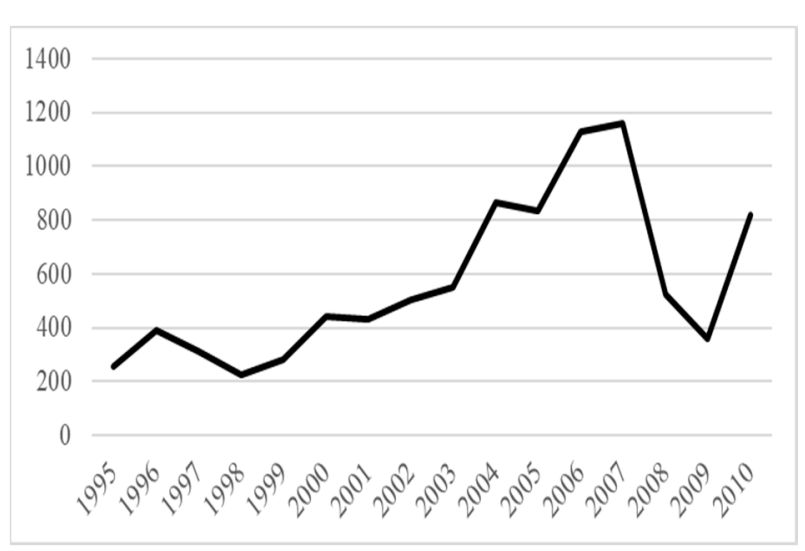

(b)

Figure 6. (a) Non-Resident Portfolio Investment (Unit: the US \$1 Billion), sourced by EIU country data; (b) Non-Resident Portfolio Investment in the US (Unit: the US \$1 Billion), sourced by EIU country data.

Thus, based on the above typical facts, we derive the following basic conclusions: (1) Investment, credit, interest rates, prices of factors of production, international capital inflows, and exchange rates show obvious pro-cyclical changes. (2) Economic volatility in developed countries may aggravate that of other countries, whereas economic volatility in small open economies cannot affect other countries. The theoretical model proposed in this study is convincing only if the change process of major economic variables in the model is consistent with the above basic facts, and only in such a theoretical model can we effectively demonstrate the impacts of saving rates and financial development on global economic volatility.

\section{Theoretical Model}

The theoretical model proposed in this study is based on Aghion et al. [18], which shows the impact of financial development on economic volatility in a small open economy. A small open economy is only a small part of the world market, and its impact on the world market is insignificant; it is not strong enough to change the economic variables such as prices, interest rates, or income in the world market. However, the theoretical model [18] does not include saving rates, the financial accelerator effect, or the impact of monetary policies on economic volatility. Furthermore, Aghion et al.'s [18] study does not include the different mechanisms of economic volatility in developed countries and emerging countries, the spillover effects of economic volatility of developed countries, and several other aspects that have been examined in this study.

\subsection{The Model Framework}

This model considers dynamic and open economies $i ; i=1$ indicates emerging countries, and $i=2$ denotes developed countries. Although several differences exist between emerging and developed countries, for this paper, we mention only three related differences: first, developed countries have high levels of financial development while emerging countries have low levels of financial development. Second, the saving rates in developed countries are low while those in emerging countries are high. The stability of investment cannot be maintained with low saving rates or low levels of financial development. Therefore, low saving rates cause economic volatility in developed countries, while lagging financial development leads to economic volatility in emerging countries. Third, as large 
open economies, changes in investment in developed countries lead to changes in interest rates in the international market, which in turn leads to changes in investment both in emerging and developed countries. As small economies, the interest rates in emerging countries are based on the exogenous interest rates in the international market, that is, changes in investment in emerging countries will not cause changes in the interest rates in the international market. Therefore, under the same conditions, the economic volatility of developed countries is more violent and has spillover effects, while that of emerging countries does not have spillover effects.

Equation (1) shows the constant elasticity of substitution (CES) production function adopted by firms.

$$
f\left(K_{i}, \omega_{i}\right)=A_{i}\left(K_{i}^{\rho_{i}}+\gamma_{i} \omega_{i}^{\rho_{i}}\right)^{1 / \rho_{i}}
$$

We assume that factor productivity $A_{i}$ is higher than the international capital market interest rate $r$. Given free trade and no capital account controls, capital $K_{i}$ can move freely between different countries, but the country-specific factor of production, $\omega_{i}$, cannot move across borders. Every country uses $K_{i}$ and $\omega_{i}$ to produce a tradable product $y_{i} \cdot \gamma_{i}$ is the weight of $\omega_{i}$ in the production function, and $\gamma_{i}>0 . \frac{1}{1-\rho_{i}}$ is the elasticity of substitution for $K_{i}$ and $\omega_{i}$, where $0 \neq \rho_{i}<1$. According to Aghion et al. [18], the country-specific factor of production can be considered as real estate. This study takes the tradable goods produced by firms as numeraire, denoted by the price of the country-specific factor $p_{i}$, and $p_{i}$ can also be interpreted as the real exchange rate.

There are $N_{i}$ banks in country $i$, and $N_{i} \geq 0$. In theory, $N_{i}=0$ also has economic meaning. However, in the real world, every country has banks, but regardless of $N_{i}>0$ or $N_{i} \geq 0$, no substantial impact affects the conclusions of our model. Therefore, in theory, $N_{i} \geq 0$ is more general. Banks do not engage in productive activities. The deposit size of each bank in countries $i$ and in period $t$ is $S_{i t}$, and $S_{i t} \geq 0 . S_{i t}$ is not equal to banks' assets, and there are two reasons. On one hand, monetary policies make the assets of banks greater or smaller than $S_{i t}$. This paper uses $M_{i t}(\cdot)$ to indicate how loose the monetary policies are, and $M_{i t}(\cdot)$. The looser the monetary policies, the larger the $M_{i t}(\cdot)$. On the other hand, banks may actively expand their balance sheets according to their economic situation. This study uses $B_{i t}(\cdot) \geq 0$ to represent the extent to which banks' balance sheets have been expanded, and $B_{i t}(\cdot) \geq 0$. As banks expand their balance sheets, $B_{i t}(\cdot) \geq 0$ increases. Thus, the assets of banks are $S_{i t} M_{i t}(\cdot) B_{i t}(\cdot)$. For the convenience of the following analysis, $M_{i t}(\cdot)$ is fixed as $\bar{M}$ and $B_{i t}(\cdot)$ is fixed as $\bar{B}$ temporarily. We hypothesize that the bank issues the $\delta_{i q}$ part of the asset $S_{i t} \bar{B} \bar{M}$ to firms as credit and $\delta_{i q} \in[0,1]$. It is assumed that the lending decisions of the banks are independent of each other, and each firm only borrows from the bank that provides the largest amount of credit to the firm. The cumulative distribution function of $\delta_{i, \max }$ is $F^{N}\left(\delta_{i, \max }\right)$, therefore, the probability density function is $N_{i} f\left(\delta_{i, \max }\right) F^{N-1}\left(\delta_{i, \max }\right)$. The credit $L_{i t}$ is:

$$
L_{i t}=S_{i t} \bar{B} \bar{M} N_{i} \int_{0}^{1} f\left(\delta_{i, \max }\right) F^{N-1}\left(\delta_{i, \max }\right) \delta_{i, \max } d \delta_{i, \max }
$$

Assuming that $\delta_{i, \max }$ is uniformly distributed on $[0,1]$, then $F\left(\delta_{i, \max }\right)=\delta_{i, \max }$ and $f\left(\delta_{i, \max }\right)=1$; therefore, $L_{i t}$ can be expressed as:

$$
L_{i t}=S_{i t} \bar{B} \bar{M} \frac{N_{i}}{N_{i}+1}
$$

The wealth of firms in period $t$ is $\Pi_{i t}$ and investment $I_{i t}$ is:

$$
I_{i t}=L_{i t}+\Pi_{i t}=S_{i t} \bar{B} \bar{M} \frac{N_{i}}{N_{i}+1}+\Pi_{i t}=\left(S_{i t} \frac{N_{i} \bar{B} \bar{M}}{N_{i} \Pi_{i t}} \frac{N_{i}}{N_{i}+1}+1\right) \Pi_{i t}
$$


We define $N_{i} S_{i t}$ as the total savings of country $i$ in period $t$, and $N_{i} \Pi_{i t}$ as the total wealth of country $i$ in period $t$; thus, the saving rate, $s_{i t}$, of country $i$ in period $t$ equals to $N_{i} S_{i t} / N_{i} \Pi_{i t}$. Therefore:

$$
I_{i t}=\left(s_{i t} \frac{N_{i} \bar{B} \bar{M}}{N_{i}+1}+1\right) \Pi_{i t}
$$

This study uses $\frac{N_{i}}{N_{i}+1}$ to measure financial development; the larger the number of banks, $N_{i}$, the higher the level of financial development and the efficiency of transforming savings into investment. $\frac{N_{i}}{N_{i}+1} \rightarrow 1$ when $N_{i} \rightarrow+\infty$, for the moment, the level of financial development is maximum, and savings are all converted into investment. $s_{i t} \frac{N_{i} \bar{B} \bar{M}}{N_{i}+1}$ determines the level of financing constraints for firms. The larger $s_{i t}$ and $N_{i}$ are, the looser will be firms' financing constraints, and the larger will be credit and investment.

As $K_{i t}=I_{i t}-p_{i t} \omega_{i}$, therefore,

$$
y_{i t}=\max _{\omega_{i}} f\left(I_{i t}-p_{i t} \omega_{i}, \omega_{i}\right)
$$

According to the first-order condition, we can obtain:

$$
y_{i t}=\psi\left(p_{i t}\right) I_{i t}
$$

and

$$
\psi\left(p_{i t}\right)=A_{i} \phi\left(p_{i t}\right)^{\frac{1-\rho_{i}}{\rho_{i}}}
$$

In Equation (4), $\phi\left(p_{i t}\right)=1+p_{i t}^{\frac{\rho_{i}}{\rho_{i}-1}} \gamma_{i}^{\frac{1}{1-\rho_{i}}}$

When firms face financing constraints, $I_{i t}=\left(s_{i t} \frac{N_{i} \bar{B} \bar{M}}{N_{i}+1}+1\right) \Pi_{i t}$. In this case, the rate of return on investment $\psi\left(p_{i t}\right)$ is greater than the international interest rate $r$, firms will expand investment as much as possible, and the market for the factors of production clears when

$$
\frac{\left(\frac{p_{i}}{\gamma_{i}}\right)^{\frac{1}{\rho_{i}-1}}\left(s_{i} \frac{N_{i} \bar{B} \bar{M}}{N_{i}+1}+1\right) \Pi_{i}}{\phi\left(p_{i}\right)}=\omega_{i}^{*}
$$

\subsection{Economic Volatility in Emerging Countries}

Assuming that emerging countries are small economies, interest rates are set by the international interest rates, namely $r$, and emerging countries' investments will not change the interest rates in the international capital market. From Aghion et al. [18], the path of economic development is analyzed from the following two aspects.

First, firms have financial constraints. At this point, $I_{1 t}=\left(s_{1 t} \frac{N_{1} \bar{B} \bar{M}}{N_{1}+1}+1\right) \Pi_{1 t}$. The rate of return on investment is greater than the interest rate, that is, $\psi\left(p_{1 t}\right)>r$. Firms invest all their wealth and credit. The dynamic equation of firms' wealth is

$$
\Pi_{1 t+1}=R_{1}+\left[\left(s_{1} t \frac{N_{1} \bar{B} \bar{M}}{N_{1}+1}+1\right) \psi\left(p_{1 t}\right)-r s_{1 t} \frac{N_{1} \bar{B} \bar{M}}{N_{1}+1}\right] \Pi_{1 t}
$$

$R_{1}$ is the exogenous output income, and Equation (6) indicates that wealth in the next period is equal to the current output minus interest, and plus the exogenous output income. Equation (5) can be written as $\left(\frac{p_{1}}{\gamma_{1}}\right)^{\frac{1}{\rho_{1}-1}} I_{1}=\omega_{1}^{*}\left(1+p_{1}^{\frac{\rho_{1}}{\rho_{1}-1}} \gamma_{1}^{\frac{1}{1-\rho_{1}}}\right)$. When taking its derivative concerning $p_{1}$ and $\Pi_{1}$ respectively, we obtain (see Appendix A):

$$
\frac{d p_{1}}{d \Pi_{1}}=\frac{\left(1-\rho_{1}\right) p_{1} \phi\left(p_{1}\right)}{\phi\left(p_{1}\right)-\rho_{1}\left[\phi\left(p_{1}\right)-1\right]} \frac{1}{\Pi_{1}}
$$


As $\rho_{1}<1, \frac{d p_{1}}{d \Pi_{1}} \geq 0$. With the growth of wealth $\Pi_{1}$, investment expands and this increases the demand for the country-specific factor of production and its price, $p_{1}$. According to Equation (4), we obtain:

$$
\psi^{\prime}\left(p_{1}\right)=-\frac{\phi\left(p_{1}\right)-1}{p_{1} \phi\left(p_{1}\right)} \psi\left(p_{1}\right)
$$

By differentiating Equation (6) and using Equations (7) and (8), we obtain (see Appendix B):

$$
\frac{d \Pi_{1 t+1}}{d \Pi_{1 t}}=\frac{\left(s_{1} \frac{N_{1} \bar{B} \bar{M}}{N_{1}+1}+1\right) \psi\left(p_{1}\right)}{\phi\left(p_{1}\right)\left(1-\rho_{1}\right)+\rho_{1}}-r s_{1} \frac{N_{1} \bar{B} \bar{M}}{N_{1}+1}
$$

According to Equation (9), the dynamic change trajectory of wealth in emerging countries is the result of the interaction between the two effects. First, it is the wealth effect. As $\frac{\left(s_{1} \frac{N_{1} \bar{M}}{N_{1}+1}+1\right) \psi\left(p_{1}\right)}{\phi\left(p_{1}\right)\left(1-\rho_{1}\right)+\rho_{1}} \geq 0$, therefore, any increase in wealth in the current period will increase wealth in the next period by expanding both investment and output. Second, it is the price effect. Because $-r s_{1} \frac{N_{1} B \bar{M}}{N_{1}+1} \leq 0$, and an increase in wealth in the current period will increase the price of the country-specific factor of production, which will reduce both profit and wealth during the next period.

The condition of economic volatility is $\frac{d \Pi_{1 t+1}}{d \Pi_{1 t}}<0$, which means:

$$
\left(s_{1} \frac{N_{1} \bar{B} \bar{M}}{N_{1}+1}+1\right) \psi\left(p_{1}\right)<\left[\phi\left(p_{1}\right)\left(1-\rho_{1}\right)+\rho_{1}\right] r s_{1} \frac{N_{1} \bar{B} \bar{M}}{N_{1}+1}
$$

According to Equation (9), when $s_{1} \frac{N_{1} \bar{B} \bar{M}}{N_{1}+1}$ is very small, for example, when $s_{1} \frac{N_{1} \bar{B}}{N_{1}+1}=0$, then $\frac{d \Pi_{1 t+1}}{d \Pi_{1 t}}>0$, and there is no economic volatility in emerging countries. Because the price effect, which is the key factor causing economic volatility, does not exist at the moment. When both sides of Equation (10) are divided by $s_{1} \frac{N_{1} \bar{B} \bar{M}}{N_{1}+1}$, it is not difficult to see that Formula (10) is more likely to be held with the gradual increase of $s_{1} \frac{N_{1} \bar{B}}{N_{1}+1}$. When $s_{1} \frac{N_{1} \bar{B} \bar{M}}{N_{1}+1}>\frac{-\psi\left(p_{1}\right)}{\psi\left(p_{1}\right)-\left[\phi\left(p_{1}\right)\left(1-\rho_{1}\right)+\rho_{1}\right] r}$ and $\psi\left(p_{1}\right)-\left[\phi\left(p_{1}\right)\left(1-\rho_{1}\right)+\rho_{1}\right] r<0$, we obtain $\frac{d \Pi_{1 t+1}}{d \Pi_{1 t}}<0$, and economic volatility exists in emerging countries at this time.

Second, when $s_{1} \frac{N_{1} \bar{B} \bar{M}}{N_{1}+1}$ is large enough and there are no financing constraints, firms only borrow less than $s_{1 t} \frac{N_{1} \bar{B} \bar{M}}{N_{1}+1} \Pi_{1 t}$ from a bank, that is, $L_{i t}<s_{1 t} \frac{N_{1} \bar{B} \bar{M}}{N_{1}+1} \Pi_{1 t}$, and face the constraint of $\psi\left(p_{1 t}\right)=r$. There is no difference between continuing to increase investment and investing wealth in the international capital market, that is, $y_{i t}-r L_{i t}=r \Pi_{1 t}$. At this point,

$$
\Pi_{1 t+1}=R_{1}+r \Pi_{1 t}
$$

and $\frac{d \Pi_{1 t+1}}{d \Pi_{1 t}}=r$.

At this point, there is no economic volatility in emerging countries.

When considering a special case with $\rho_{1} \rightarrow-\infty$, at this point, the production function degenerates into the Leontief form. When $s_{1} \frac{N_{1} \bar{B} \bar{M}}{N_{1}+1}$ is small, investment is not sufficient to consume the country-specific factor of production, $\omega_{1}$. According to the characteristics of the Leontief production function, if there is a surplus of $\omega_{1}$, its price $p_{1}$ equals zero, and the output $y_{i t}=A_{1} I_{i t}$. The dynamic equation of firms' wealth is $\Pi_{1 t+1}=R_{1}+$ $\left[A_{1}\left(s_{1} \frac{N_{1} \bar{B} \bar{M}}{N_{1}+1}+1\right)-s_{1} \frac{N_{1} \bar{B} \bar{M}}{N_{1}+1} r\right] \Pi_{1 t}$, therefore, $\frac{d \Pi_{1 t+1}}{d \Pi_{1 t}}=A_{1}\left(s_{1} \frac{N_{1} \bar{B} \bar{M}}{N_{1}+1}+1\right)-s_{1} \frac{N_{1} \bar{B} \bar{M}}{N_{1}+1} r>0$. In 
this case, there was no economic volatility. As $s_{1} \frac{N_{1} \bar{B} \bar{M}}{N_{1}+1}$ increases, $\omega_{1}$ is insufficient to meet investment needs gradually; therefore, $p_{1}>0$. Substituting $\rho_{1} \rightarrow-\infty$ into Equation (9), we find that $\frac{d \Pi_{1 t+1}}{d \Pi_{1 t}}=-s_{1} \frac{N_{1} \bar{B} \bar{M}}{N_{1}+1} r<0$, there is economic volatility, and $\frac{d \Pi_{1 t+1}}{d \Pi_{1 t}}$ takes its minimum.

This is because when $\rho_{1} \rightarrow-\infty$, the elasticity of substitution reaches a minimum, and it is the most difficult time to replace the country-specific factor of production by capital; therefore, its prices will fluctuate more. As a result, emerging countries are more likely to experience severer economic volatility. When $s_{1} \frac{N_{1} \bar{B} \bar{M}}{N_{1}+1}$ is sufficiently large, the wealth dynamic equation is given by Equation (11). Thus, $\frac{d \Pi_{1 t+1}}{d \Pi_{1 t}}=r$, and there is no economic volatility in emerging countries. By using the Leontief production function (when $\rho_{1} \rightarrow-\infty$ ), we can obtain the conclusions of this study more directly, and it will be easier to understand the economic meaning of the theoretical model.

In conclusion, when $s_{1} \frac{N_{1} \bar{B} \bar{M}}{N_{1}+1}$ is either very large or very small, emerging countries do not experience economic volatility; only when $s_{1} \frac{N_{1} \bar{B} \bar{M}}{N_{1}+1}$, firms' financing constraints are at a medium level can there be economic volatility. Matsuyama, Kunieda, and Shibata reached a similar conclusion based on the overlapping generation model [36,37]. In emerging countries, saving rates are very high, and if their financial development levels are also very high, $s_{1} \frac{N_{1} \bar{B} \bar{M}}{N_{1}+1}$ increases and become very large, and the economic development trajectory of emerging countries will be as shown in Formula (11), without economic volatility. Due to the low levels of financial development in emerging countries, $s_{1} \frac{N_{1} \bar{B} \bar{M}}{N_{1}+1}$ may be at the middle level, resulting in economic volatility. Reducing the saving rates of emerging countries can smooth economic volatility, but this could be at the cost of increasing the financing constraints of firms and reducing investment and wealth. Finally, the economy converges to a lower level of equilibrium.

In the theoretical model, the mechanism of economic volatility is as follows: First, firms borrow money from banks to expand investments; initially, the price of the countryspecific factor of production does not rise significantly, and the wealth effect occupies a dominant position. In such circumstances, firms' profits continue to rise, and international capital inflows to share the wealth, which causes the exchange rate to rise. The continuous increase in investment makes the demand and price of the country-specific factor of production rise sharply. As a result, the price effect begins to occupy a dominant position, resulting in reducing the inflow of international capital, investment, output, and wealth. Consequently, the demand and price of the country-specific factors of production begin to decline. When the price of the country-specific factor of production falls to a certain level that makes investment profitable again, the above economic variables will move in the opposite direction to start a new cycle of economic prosperity.

The pro-cyclical change process of each economic variable is consistent with that of previous economic crises. When financial development is inadequate in emerging countries, it is difficult to convert high savings into effective investments; as a result, emerging countries find it difficult to provide a constant supply of funds for sustained economic growth. During an economic downturn, it is difficult to ease firms' financing constraints to prevent the shrinkage of investment, output, and other variables. Thus, it is difficult for emerging countries to avoid economic volatility.

The model shows that the price of the country-specific factor of production plays an important role in economic volatility. Referring to the existing literature, the country-specific factor of production can be deemed as real estate, therefore, house prices play a crucial role in economic volatility. Before the 1997 Asian financial crisis and the subprime mortgage crisis in 2008, the real estate industry had experienced rapid growth in several countries. As a result, housing prices soared, and economic prosperity progressed. However, after the bubble burst, house prices plummeted, and the economic activity slowed down. Historical 
experience also shows that as the real estate sector contributes significantly to the economy, house prices have a major impact on economic volatility and economic crises.

In addition to house prices $p_{1}$, factor productivity $A_{1}$ also has an impact on economic volatility. As $\psi\left(p_{1 t}\right)=A_{1} \phi\left(p_{1 t}\right)^{\frac{1-\rho_{1}}{\rho_{1}}}, \psi\left(p_{1 t}\right)$ increases as $A_{1}$ increases, which causes $\frac{d \Pi_{1 t+1}}{d \Pi_{1 t}}$ in Formula (9) to augment. Therefore, an increase in factor productivity $A_{1}$, which can largely be represented by technological progress, will reduce economic volatility. The mechanism is that increase in $A_{1}$ will raise the rate of return on investment, namely $\psi\left(p_{1 t}\right)$ and the expanding wealth effect will offset the adverse impact of the price effect caused by the rise in the price of $\omega_{i}$ on investment and wealth, and this alleviates an economic recession and promotes the accumulation of firms' wealth.

Finally, this study investigates the impact of interest rates on economic volatility. It can be observed that the smaller the $r$, the larger the $\frac{d \Pi_{1 t+1}}{d \Pi_{1 t}}$, and the economy is less volatile. The underlying mechanism is also very simple. Cutting interest rates reduces costs for firms and stimulates investment. In particular, when interest rates are equal to or smaller than zero, $\frac{d \Pi_{1 t+1}}{d \Pi_{1 t}} \geq 0$, the economy can effectively avert economic volatility. Since the 2008 economic recession, some countries set legal interest rates equal to zero, so real interest rates may be negative, and our model shows that these policies have a theoretical basis and can effectively alleviate or even avoid sharp economic volatility and economic crises.

\subsection{Economic Volatility in Developed Countries and Their International Spillover Effects}

\subsubsection{Economic Volatility in Developed Countries}

Similar to Equation (6), when firms have financing constraints, the wealth dynamic equation of developed countries is:

$$
\Pi_{2 t+1}=R_{2}+\left[\left(s_{2 t} \frac{N_{2} \bar{B} \bar{M}}{N_{2}+1}+1\right) \psi\left(p_{2 t}\right)-r s_{2 t} \frac{N_{2} \bar{B} \bar{M}}{N_{2}+1}\right] \Pi_{2 t}
$$

Based on the analysis of economic volatility in emerging countries, when $s_{2} \frac{N_{2} \bar{B} \bar{M}}{N_{2}+1}$ is intermediate, but not very small or very large, developed countries experience economic volatility. House prices have a major impact on economic volatility. Technological progress reduces economic volatility in developed countries. Cutting interest rates also eases economic volatility. Developed countries have high levels of financial development; however, their saving rates are very low, so that $s_{2} \frac{N_{2} \bar{B} \bar{M}}{N_{2}+1}$ may be intermediate; therefore, $\frac{d \Pi_{2 t+1}}{d \Pi_{2 t}}$ will be negative, and the economies of developed countries will have more fluctuations. Reducing the levels of financial development in developed countries can also smooth economic volatility, but this will be at the cost of increasing firms' financing constraints and reducing their investments and wealth; as a result, the economy will finally converge to a lower equilibrium.

Unlike emerging countries, which are small economies, developed countries can be considered as large economies. Changes in investment will change international interest rates. When investments in developed countries expand, international interest rates will rise. Otherwise, international interest rates fall. Based on this characteristic of large and developed economies, this study makes $r_{t}=r\left(I_{2 t}\right)$, and $\frac{d r_{t}}{d I_{2 t}}>0$. The derivative of Equation (12) is:

$$
\begin{gathered}
\frac{d \Pi_{2 t+1}}{d \Pi_{2 t}}=\frac{\left(s_{2} \frac{N_{2} \bar{B} \bar{M}}{N_{2}+1}+1\right) \psi\left(p_{2}\right)}{\phi\left(p_{2}\right)\left(1-\rho_{2}\right)+\rho_{2}}-r\left(I_{2}\right) s_{2} \frac{N_{2} B \bar{M}}{N_{2}+1}-s_{2} \frac{N_{2} \bar{B} \bar{M}}{N_{2}+1} \Pi_{2 t}\left(s_{2} \frac{N_{2} \bar{B} \bar{M}}{N_{2}+1}+1\right) \frac{d r_{t}}{d I_{2 t}} \\
\text { As }-s_{2} \frac{N_{2} \bar{B} \bar{M}}{N_{2}+1} \Pi_{2 t}\left(s_{2} \frac{N_{2} \bar{B} \bar{M}}{N_{2}+1}+1\right) \frac{d r_{t}}{d I_{2 t}}<0, \text { under the same conditions, } \frac{d \Pi_{2 t+1}}{d \Pi_{2 t}} \text { in Equation }
\end{gathered}
$$

is smaller than $\frac{d \Pi_{1 t+1}}{d \Pi_{1 t}}$ in Equation (9), indicating that developed countries are more likely to generate extreme economic volatility than emerging countries under the same conditions. 


\subsubsection{Spillover Effects of Economic Volatility in Developed Countries}

As large and open economies, any change in investments in developed countries will alter international interest rates. This not only fluctuates interest rates but also becomes a cause of economic volatility and disturbs the economies of other countries. For example, before the 2008 global economic recession, the sustained huge investment in the US had formed asset bubbles and pushed the rate of inflation higher, forcing the Federal Reserve (Fed) to raise interest rates promptly and repeatedly. Figure $5 \mathrm{~b}$ shows that during most periods, emerging countries' real interest rates followed those of the U.S. The increase in interest rates was one of the factors that triggered the 2008 global economic recession.

As small economies, the change in investments in emerging countries will not alter interest rates in the global market, and the economic volatility of emerging countries will not produce spillover effects and affect other countries. When analyzing the international spillover effects of economic volatility in developed countries, we must analyze it based on the following two models: first, the two-country model of two developed countries; second, the two-country model of one developed country and one emerging country.

\section{Spillover Effects of Economic Volatility in Developed Countries on Other} Developed Countries

The analysis of the spillover effects of economic volatility in developed countries should be carried out in two ways. First, the business cycles of two developed countries are in the same direction. Let $i=3$ represent another developed country. As the business cycles of the two countries are synchronized, therefore, $\Pi_{3 t}=\Pi_{3 t}\left(\Pi_{2 t}\right)$, and $\frac{d \Pi_{3 t}}{d \Pi_{2 t}}>0$. As the two developed countries are big economies, the change in investment in each country alters the international interest rates. Thus, interest rates in the international capital market are a function of investments in the two developed countries. When investment expands in each developed country, the international interest rates will rise; otherwise, the interest rates will decrease. Therefore, the international interest rates can be written as $r_{t}=r\left(I_{2 t}, I_{3 t}\right)$, $\frac{d r_{t}}{d I_{2 t}}>0$, and $\frac{d r_{t}}{d I_{3 t}}>0$. When considering the spillover effects of economic volatility among developed countries, Equation (13) becomes

$$
\begin{aligned}
\frac{d \Pi_{2 t+1}}{d \Pi_{2 t}}=\frac{\left(s_{2} \frac{N_{2}-\bar{B}}{N_{2}+1}+1\right) \psi\left(p_{2}\right)}{\phi\left(p_{2}\right)\left(1-\rho_{2}\right)+\rho_{2}} & -r\left(I_{2 t}, I_{3 t}\right) s_{2} \frac{N_{2} \bar{B} \bar{M}}{N_{2}+1}-s_{2} \frac{N_{2} \bar{B} \bar{M}}{N_{2}+1} \Pi_{2 t}\left[\left(s_{2} \frac{N_{2} \bar{B} \bar{M}}{N_{2}+1}+1\right) \frac{d r\left(I_{2 t}, I_{3 t}\right)}{d I_{2 t}}\right. \\
& \left.+\left(s_{3} \frac{N_{3}-\bar{B} \bar{M}}{N_{3}+1}+1\right) \frac{d r\left(I_{2 t}, I_{3 t}\right)}{d I_{3 t}} \frac{d \Pi_{3 t}}{d \Pi_{2 t}}\right]
\end{aligned}
$$

As $-s_{2} \frac{N_{2} \bar{B} \bar{M}}{N_{2}+1} \Pi_{2 t}\left(s_{3} \frac{N_{3} \bar{B} \bar{M}}{N_{3}+1}+1\right) \frac{d r\left(I_{2 t} I_{3 t}\right)}{d I_{3 t}} \frac{d \Pi_{3 t}}{d \Pi_{2 t}}<0, \frac{d \Pi_{2 t+1}}{d \Pi_{2 t}}$ in Equation (14) is smaller than that obtained by Equation (13). It shows that under the same conditions when the business cycles of the two developed countries are synchronized, "co-frequency resonance" occurs and aggravates the domestic economic volatility of each developed country. The economic logic is that investments change in the same direction in both countries, thereby aggravating the disturbance of interest rates and further amplifying economic volatility. When the business cycles of the two developed countries are reversed, $\frac{d \Pi_{3 t}}{d \Pi_{2 t}}<0$. $\frac{d \Pi_{2 t+1}}{d \Pi_{2 t}}$ in Equation (14) is larger than that obtained using Equation (13). This shows that under the same conditions when the business cycles of the two developed countries are opposite, the reverse change in the investments of the two countries reduces the impact of interest rate fluctuations on their domestic economies and alleviates economic volatility in both countries.

\section{Spillover Effects of Economic Volatility in Developed Countries on Emerging Countries}

In the analysis of economic volatility in emerging countries, interest rates are assumed to be exogenous. In the two-country model of an emerging country and a developed country, it is necessary to consider the impact of economic volatility of developed countries on the changes in international interest rates and the spillover effects of developed countries' economic volatility on emerging countries. Similarly, the analysis is going to be conducted 
based on two aspects. First, the business cycles of both emerging and developed countries are in the same direction. At this point, $\Pi_{2 t}=\Pi_{2 t}\left(\Pi_{1 t}\right)$, and $\frac{d \Pi_{2 t}}{d \Pi_{1 t}}>0$. Interest rates in the international capital market are only affected by investments in developed countries; therefore $r_{t}=r\left(I_{2 t}\right)$, and $\frac{d r_{t}}{d I_{2 t}}>0$. When considering the spillover effects of the economic volatility of developed countries on emerging countries, Equation (9) will be written as:

$$
\frac{d \Pi_{1 t+1}}{d \Pi_{1 t}}=\frac{\left(s_{1} \frac{N_{1} \bar{B} \bar{M}}{N_{1}+1}+1\right) \psi\left(p_{1}\right)}{\phi\left(p_{1}\right)\left(1-\rho_{1}\right)+\rho_{1}}-r_{t} s_{1} \frac{N_{1} \bar{B} \bar{M}}{N_{1}+1}-s_{1} \frac{N_{1} \bar{B} \bar{M}}{N_{1}+1}\left(s_{2} \frac{N_{2} \bar{B} \bar{M}}{N_{2}+1}+1\right) \Pi_{1 t} \frac{d r_{t}}{d I_{2 t}} \frac{d \Pi_{2 t}}{d \Pi_{1 t}}
$$

It can be observed that $\frac{d \Pi_{1 t+1}}{d \Pi_{1 t}}$ in Equation (15) is smaller than that given by Equation (9). This shows that under the same conditions when the business cycles of both emerging and developed countries are in the same direction, the economic volatility of developed countries spills over into emerging countries. At this time, the price of the country-specific factor of production will change in the same direction as the international interest rates, resulting in a stronger price effect and aggravating the economic volatility of emerging countries. When the economic cycle of an emerging country is reversed from that of a developed country, $\frac{d \Pi_{2 t}}{d \Pi_{1 t}}<0$. $\frac{d \Pi_{1 t+1}}{d \Pi_{1 t}}$ in Equation (15) is larger than that obtained by Equation (9). Under the same conditions, compared with the one-country model, the economic volatility of emerging countries in the two-country model has been alleviated. At this time, interest rates in the global capital market change in the opposite direction with the price of the country-specific factor of production in emerging countries, which is conducive to reducing the price effect on the economic volatility of emerging countries.

In the real world, the economies of various countries are often interdependent, and business cycles are often synchronous. Therefore, economic volatility in developed countries tends to spread to other countries, exacerbating economic volatility in other developed and emerging countries.

\subsection{Impacts of the Financial Accelerator Effect and Monetary Policies on Economic Volatility}

After analyzing the economic volatility in both emerging and developed countries and their spillover effects, this study examines the financial accelerator effect of procyclical changes in banks' balance sheets and the impact of monetary policies on economic volatility.

\subsubsection{Financial Accelerator Effect}

The model above does not consider the impact of cyclical changes in banks' balance sheets on economic volatility, as $B_{i t}(\cdot)$ is fixed as $\bar{B}$. In the real world, banks adjust their balance sheets according to the economic situation. Banks tend to expand their balance sheets during boom periods and shrink them during recessions. Procyclical changes in banks' balance sheets act as financial accelerators, amplifying economic volatility. Therefore, it is necessary to analyze the impact of procyclical changes in banks' balance sheets on economic volatility.

Let $B_{i t}(\cdot)=B\left(\Pi_{i t}\right)$, and $\frac{d B\left(\Pi_{i t}\right)}{d \Pi_{i t}}>0$. After considering the procyclical response behavior of banks, Equation (9) should be rewritten as (see Appendix $C$ ):

$$
\frac{d \Pi_{1 t+1}}{d \Pi_{1 t}}=\frac{\left(s_{1} \frac{N_{1} B\left(\Pi_{1 t}\right) \bar{M}}{N_{1}+1}+1\right) \psi\left(p_{1}\right)}{\phi\left(p_{1}\right)\left(1-\rho_{1}\right)+\rho_{1}}-r s_{1} \frac{N_{1} B\left(\Pi_{1 t}\right) \bar{M}}{N_{1}+1}+\left[\frac{\psi\left(p_{1}\right)}{\phi\left(p_{1}\right)\left(1-\rho_{1}\right)+\rho_{1}}-r\right] s_{1} \frac{N_{1} \bar{M}}{N_{1}+1} \Pi_{1 t} \frac{d B\left(\Pi_{1 t}\right)}{d \Pi_{1 t}}
$$

If there is economic volatility in emerging countries, it indicates that $\psi\left(p_{1}\right)-\left[\phi\left(p_{1}\right)\left(1-\rho_{1}\right)+\rho_{1}\right] r<0$; in this case, $\left[\frac{\psi\left(p_{1}\right)}{\phi\left(p_{1}\right)\left(1-\rho_{1}\right)+\rho_{1}}-r\right] s_{1} \frac{N_{1} M}{N_{1}+1} \Pi_{1 t} \frac{d B\left(\Pi_{1 t}\right)}{d \Pi_{1 t}}<0$. $\frac{d \Pi_{1 t+1}}{d \Pi_{1 t}}$ obtained by Equation (16) is smaller than that in Equation (9). Therefore, under the same conditions, considering the procyclical response behavior of banks will make emerging countries more prone to generate more severe economic volatility.

Similarly, Equation (13) is rewritten as: 


$$
\begin{aligned}
& \frac{d \Pi_{2 t+1}}{d \Pi_{2 t}}=\frac{\left(s_{2} \frac{N_{2} B\left(\Pi_{2}\right) \bar{M}}{N_{2}+1}+1\right) \psi\left(p_{2}\right)}{\phi\left(p_{2}\right)\left(1-\rho_{2}\right)+\rho_{2}}-r_{t} s_{2} \frac{N_{2} B\left(\Pi_{2 t}\right) \bar{M}}{N_{2}+1}-s_{2} \frac{N_{2} B\left(\Pi_{2 t}\right) \bar{M}}{N_{2}+1} \Pi_{2 t}\left(s_{2} \frac{N_{2} B\left(\Pi_{2 t}\right) \bar{M}}{N_{2}+1}+1\right) \frac{d r_{t}}{d I_{2 t}} \\
& +\left[\frac{\psi\left(p_{2}\right)}{\phi\left(p_{2}\right)\left(1-\rho_{2}\right)+\rho_{2}}-r_{t}\right] s_{2} \frac{N_{2} \bar{M}}{N_{2}+1} \Pi_{2 t} \frac{d B\left(\Pi_{2 t}\right)}{d \Pi_{2 t}}
\end{aligned}
$$

$\frac{d \Pi_{2 t+1}}{d \Pi_{2 t}}$ in Equation (17) is smaller than that in Equation (13). Therefore, under the same conditions, the procyclical response behavior of banks will also make the developed countries more prone to produce more severe economic volatility.

Thus, under the same conditions, pro-cyclical changes in banks' balance sheets will cause more severe economic volatility in both developed and emerging countries.

\subsubsection{The Impact of Monetary Policies on Economic Volatility}

In the above analysis, this study does not consider the impact of monetary policies on economic volatility, and $M_{i t}(\cdot)$ is fixed as $\bar{M}$ for convenience. In the real world, a central bank's monetary policy is not fixed. When the economy is excessively prosperous, the country's central bank usually implements tight monetary policies to prevent overheating of the economy and provides room for future monetary policies. In an economic recession, the central bank often implements expansionary monetary policies to stimulate the economy. Given the countercyclical characteristic of monetary policies, let $M_{i t}(\cdot)=M\left(\Pi_{i t}\right)$ and $\frac{d \Pi_{1 t+1}}{d \Pi_{1 t}}<0$. After considering the countercyclical monetary policies, Equation (9) can be rewritten as:

$$
\frac{d \Pi_{1 t+1}}{d \Pi_{1 t}}=\frac{\left(s_{1} \frac{N_{1} M\left(\Pi_{1 t}\right) \bar{B}}{N_{1}+1}+1\right) \psi\left(p_{1}\right)}{\phi\left(p_{1}\right)\left(1-\rho_{1}\right)+\rho_{1}}-r s_{1} \frac{N_{1} M\left(\Pi_{1 t}\right) \bar{B}}{N_{1}+1}+\left[\frac{\psi\left(p_{1}\right)}{\phi\left(p_{1}\right)\left(1-\rho_{1}\right)+\rho_{1}}-r\right] s_{1} \frac{N_{1} \bar{B}}{N_{1}+1} \Pi_{1 t} \frac{d M\left(\Pi_{1 t}\right)}{d \Pi_{1 t}}
$$

If there is economic volatility in emerging countries, it indicates that $\psi\left(p_{1}\right)-\left[\phi\left(p_{1}\right)\left(1-\rho_{1}\right)+\rho_{1}\right] r<0$; in this case, $\frac{d \Pi_{1 t+1}}{d \Pi_{1 t}}$ in Equation (18) is larger than that in Equation (9). At this time, the economic volatility of emerging countries has been alleviated.

Similarly, Equation (13) can be rewritten as:

$$
\begin{gathered}
\frac{d \Pi_{2 t+1}}{d \Pi_{2 t}}=\frac{\left(s_{2} \frac{N_{2} M\left(\Pi_{2 t}\right) \bar{B}}{N_{2}+1}+1\right) \psi\left(p_{2}\right)}{\phi\left(p_{2}\right)\left(1-\rho_{2}\right)+\rho_{2}}-r_{t} s_{2} \frac{N_{2} M\left(\Pi_{2 t}\right) \bar{B}}{N_{2}+1}-s_{2} \frac{N_{2} M\left(\Pi_{2 t}\right) \bar{B}}{N_{2}+1} \Pi_{2 t}\left(s_{2} \frac{N_{2} M(\Pi) \bar{B}}{N_{2}+1}+1\right) \frac{d r_{t}}{d I_{2 t}} \\
+\left[\frac{\psi\left(p_{2}\right)}{\phi\left(p_{2}\right)\left(1-\rho_{2}\right)+\rho_{2}}-r_{t}\right] s_{2} \frac{N_{2} \bar{B}}{N_{2}+1} \Pi_{2 t} \frac{d M\left(\Pi_{2 t}\right)}{d \Pi_{2 t}}
\end{gathered}
$$

Similarly, $\frac{d \Pi_{2 t+1}}{d \Pi_{2 t}}$ in Equation (19) is larger than that in Equation (13). Thus, the economic volatility of developed countries has been alleviated. In other words, countercyclical monetary policies reduce the economic volatility of both emerging and developed countries and reduce the spillover effects of economic volatility in developed countries. When the economy is excessively prosperous, implementation of tight monetary policies increases firms' financing constraints and reduces investments of firms, and prevents the excessive rise of interest rates, the price of the country-specific factor of production, and excessive economic growth. During an economic recession, the implementation of loose monetary policies is conducive to easing the financing constraints of firms, as it increases firms' investments, output, and profits, and the price of the country-specific factor of production and interest rates.

\section{Conclusions and Policy Implications}

All previous economic crises provide the best opportunity to study the mechanism of economic volatility and have enabled scholars to explore the various causes of economic volatility, broadly and constantly. Some studies show that low saving rates and inadequate financial development triggered the Latin American economic crisis during the 1980s, the Asian financial crisis in the late 1990s, and the global economic recession in 2008; however, 
there is a lack of a unified and normative theoretical framework to illustrate the impact of low saving rates on the economic volatility of developed countries, and the impact of lagging financial development on the economic volatility of emerging countries.

This study constructs a dynamic and open economy model to analyze these problems normatively. The model shows that it is difficult for developed countries to maintain investments stability and provide a continuous supply of capital for sustained economic growth with low saving rates. When the price of the country-specific factor of production and interest rates rise, the profit and credit value of firms decline. Because of the low saving rates, developed countries cannot provide sufficient capital to ease firms' financing constraints to prevent the shrinkage of investment, output, and other variables. Therefore, it is difficult for developed countries to avoid economic recessions. Due to the low levels of financial development, it is difficult to ease firms' financing constraints in emerging countries. Emerging countries find it difficult to convert high savings into effective investments to maintain sustained economic growth or prevent an economic recession. Finally, economic volatility in emerging countries cannot be avoided.

Under the same conditions, as large economies, developed countries experience more severe economic volatility than emerging countries; moreover, their economic volatility has international spillover effects that aggravate the economic volatility of other countries. Thus, any change in developed countries' investments will change the interest rates in the global capital market, and this change in interest rates will become another source of global economic volatility. As small economies, investments changes in emerging countries cannot affect interest rates in the international capital market, and the economic volatility of emerging countries has no spillover effects.

In addition, the theoretical model also finds that banks' pro-cyclical behavior plays the catalytic role of a financial accelerator, amplifying and aggravating economic volatility. As banks' balance sheets change in a pro-cyclical way, firms' financing constraints are relaxed during a boom, resulting in larger credit, investment, and output. However, during an economic recession, firms' financing constraints are very tight, thereby leading to further shrinkage of credit, investment, and output. The effect and mechanism of countercyclical monetary policies are opposite to those of banks' pro-cyclical behavior. Central banks' countercyclical monetary policies can mitigate economic volatility; in particular, if the real interest rates are equal to or less than zero, countries can effectively avert economic volatility. The theoretical model also shows that technological progress is conducive to improving the rate of return on investment and slowing down economic volatility. The change in the price of the country-specific factor of production, namely house prices, plays a crucial role in economic volatility.

To avert drastic economic volatility and a global economic recession, developed countries must increase their saving rates in the long run, while emerging countries should gradually improve the levels of financial development to ease firms' financing constraints and avoid a sharp decline in firms' investments. In the short term, as house prices are the key to economic volatility, preventing an excessive rise in real estate prices can reduce economic volatility. At the same time, when the economy is in a recession, reducing interest rates will help to decrease firms' costs and improve the rate of return on investment, especially reducing the spillover effects of economic volatility in developed countries. Meanwhile, implementation of countercyclical monetary policies and reducing the procyclical reaction of banks will help to restore the credit value of firms and temporarily ease their financing constraints, and this can help to prevent a sharp decline in investment and avoid an economic recession. From the perspective of foreign economic policies, controlling the capital account and stabilizing the exchange rate temporarily will help to reduce the impact of international capital outflow on domestic economic volatility during an economic downturn. Finally, technological progress is also a driving force to promote economic growth and prevent economic recessions.

For the sake of simplicity and the convenience of the readers in understanding the economic meaning of this theoretical model, financial development and saving rates are 
exogenous in the model, which may be a limitation of this paper. Therefore, as future research one can establish an economic volatility model with endogenous financial development and saving rates. Another research direction can be based on Zavadskas et al. [38] by introducing uncertainty, information asymmetry, and enterprise default into the model, which will make the theoretical model more consistent with the reality and increase the explanatory power of the model. In this case, firms may go bankrupt and incur liquidation and reorganization costs. Under the same conditions, the world will have a more serious recession and more severe economic volatility.

Author Contributions: Conceptualization, H.Z.; methodology, H.L.; software, H.Z.; validation, S.L.; formal analysis, H.L.; data curation, S.L.; writing-original draft preparation, H.Z. and H.L.; writingreview and editing, H.Z.; visualization, S.L. All authors have read and agreed to the published version of the manuscript.

Funding: This research was funded by the Starting Research Fund from Zhejiang Sci-Tech University (No. 20092343-Y).

Institutional Review Board Statement: Not applicable.

Informed Consent Statement: Not applicable.

Data Availability Statement: Not applicable.

Conflicts of Interest: The authors declare no conflict of interest.

\section{Appendix A}

After the total differentiation of Equation (5), we get:

$$
\begin{aligned}
& \frac{1}{\rho_{1}-1}\left(\frac{p_{1}}{\gamma_{1}}\right)^{\frac{2-\rho_{1}}{\rho_{1}-1}} \frac{1}{\gamma_{1}}\left(s_{1} \frac{N_{1} \bar{B} \bar{M}}{N_{1}+1}+1\right) \Pi_{1} d p_{1}+\left(\frac{p_{1}}{\gamma_{1}}\right)^{\frac{1}{\rho_{1}-1}}\left(s_{1} \frac{N_{1} \bar{B} \bar{M}}{N_{1}+1}+1\right) d \Pi_{1} \\
& =\omega_{1}^{*} \frac{\rho_{1}}{\rho_{1}-1} p_{1}^{\frac{1}{\rho_{1}-1}} \gamma_{1}^{\frac{1}{1-\rho_{1}}} d p_{1} \\
& =\frac{\left(\frac{p_{1}}{\gamma_{1}}\right)^{\frac{1}{\rho_{1}-1}}\left(s_{1} \frac{N_{1} B \bar{M}}{N_{1}+1}+1\right) \Pi_{1}}{\phi\left(p_{1}\right)} \frac{\rho_{1}}{\rho_{1}-1} p_{1}{ }^{\frac{1}{\rho_{1}-1}} \gamma_{1}^{\frac{1}{1-\rho_{1}}} d p_{1}
\end{aligned}
$$

After both sides are divided by $\left(\frac{p_{1}}{\gamma_{1}}\right)^{\frac{1}{\rho_{1}-1}}$, then multiplied by $p_{1}$, and divided by $\left(s_{1} \frac{N_{1} \bar{B} \bar{M}}{N_{1}+1}+1\right)$, we find that

$$
\frac{1}{\rho_{1}-1} \Pi_{1} d p_{1}+p_{1} d \Pi_{1}=\frac{\rho_{1}}{\rho_{1}-1} \frac{\phi\left(p_{1}\right)-1}{\phi\left(p_{1}\right)} \Pi_{1} d p_{1}
$$

After term shifting and simplification, we obtain Equation (7).

\section{Appendix B}

After total differentiation of Equation (6), we obtain:

$$
\begin{aligned}
& \left(s_{1} \frac{N_{1} \bar{B} \bar{M}}{N_{1}+1}+1\right) \psi\left(p_{1}\right)+\left(s_{1} \frac{N_{1} \bar{B} \bar{M}}{N_{1}+1}+1\right) \Pi_{1} \psi^{\prime}\left(p_{1}\right) \frac{d p_{1}}{d \Pi_{1}}-r s_{1} \frac{N_{1} \bar{B} \bar{M}}{N_{1}+1} \\
& =\left(s_{1} \frac{N_{1} \bar{B}}{N_{1}+1}+1\right) \psi\left(p_{1}\right)-\left(s_{1} \frac{N_{1} \bar{B}}{N_{1}+1}+1\right) \frac{\phi\left(p_{1}\right)-1}{p_{1} \phi\left(p_{1}\right)} \psi\left(p_{1}\right) \Pi_{1} \frac{\left(1-\rho_{1}\right) p_{1} \phi\left(p_{1}\right)}{\phi\left(p_{1}\right)-\rho_{1}\left[\phi\left(p_{1}\right)-1\right]} \frac{1}{\Pi_{1}}-r s_{1} \frac{N_{1} \bar{B} \bar{M}}{N_{1}+1} \\
& =\left(s_{1} \frac{N_{1} \bar{B} \bar{M}}{N_{1}+1}+1\right) \psi\left(p_{1}\right)-\left(s_{1} \frac{N_{1} \bar{B} \bar{M}}{N_{1}+1}+1\right) \frac{\psi\left(p_{1}\right)\left(\phi\left(p_{1}\right)-1\right)\left(1-\rho_{1}\right)}{\phi\left(p_{1}\right)-\rho_{1}\left[\phi\left(p_{1}\right)-1\right]}-r s_{1} \frac{N_{1} \bar{B} \bar{M}}{N_{1}+1} \\
& =\left(s_{1} \frac{N_{1} \bar{B} \bar{M}}{N_{1}+1}+1\right) \psi\left(p_{1}\right)\left[1-\frac{\left(\phi\left(p_{1}\right)-1\right)\left(1-\rho_{1}\right)}{\phi\left(p_{1}\right)-\rho_{1}\left[\phi\left(p_{1}\right)-1\right]}\right]-r s_{1} \frac{N_{1} B \bar{B}}{N_{1}+1}
\end{aligned}
$$

After simplification, we obtain Equation (9). 


\section{Appendix C}

The total differential of Equation (5) is as follows:

$$
\begin{aligned}
& \frac{1}{\rho_{1}-1}\left(\frac{p_{1}}{\gamma_{1}}\right)^{\frac{2-\rho_{1}}{\rho_{1}-1}} \frac{1}{\gamma_{1}}\left(s_{1} \frac{N_{1} B\left(\Pi_{1}\right) \bar{M}}{N_{1}+1}+1\right) \Pi_{1} d p_{1}+\left(\frac{p_{1}}{\gamma_{1}}\right)^{\frac{1}{\rho_{1}-1}} s_{1} \frac{N_{1} \bar{M}}{N_{1}+1} \Pi_{1} \frac{d B\left(\Pi_{1}\right)}{d \Pi_{1}} d \Pi_{1}+\left(\frac{p_{1}}{\gamma_{1}}\right)^{\frac{1}{\rho_{1}-1}}\left(s_{1} \frac{N_{1} B\left(\Pi_{1}\right) \bar{M}}{N_{1}+1}+1\right) d \Pi_{1} \\
& =\omega_{1}^{*} \frac{\rho_{1}}{\rho_{1}-1} p_{1}^{\frac{1}{\rho_{1}-1}} \gamma_{1}^{\frac{1}{1-\rho_{1}}} d p_{1} \\
& =\frac{\left(\frac{p_{1}}{\gamma_{1}}{\frac{1}{\rho_{1}-1}}^{\frac{1}{\rho_{1}}}\left(s_{1} \frac{N_{1} B\left(\Pi_{1}\right) \bar{M}}{N_{1}+1}+1\right) \Pi_{1}\right.}{\phi\left(p_{1}\right)} \frac{\rho_{1}}{\rho_{1}-1} p_{1}^{\frac{1}{\rho_{1}-1}} \gamma_{1}^{\frac{1}{1-\rho_{1}}} d p_{1}
\end{aligned}
$$

After both sides are divided by $\left(\frac{p_{1}}{\gamma_{1}}\right)^{\frac{1}{\rho_{1}-1}}$, and multiplied by $p_{1}$, then divided by $\left(s_{1} \frac{N_{1} B\left(\Pi_{1}\right) \bar{M}}{N_{1}+1}+1\right)$, we obtain

$$
\frac{1}{\rho_{1}-1} \Pi_{1} d p_{1}+\frac{s_{1} \frac{N_{1} \bar{M}}{N_{1}+1}}{s_{1} \frac{N_{1} B\left(\Pi_{1}\right) \bar{M}}{N_{1}+1}+1} \Pi_{1} p_{1} \frac{d B\left(\Pi_{1}\right)}{d \Pi_{1}} d \Pi_{1}+p_{1} d \Pi_{1}=\frac{\rho_{1}}{\rho_{1}-1} \frac{\phi\left(p_{1}\right)-1}{\phi\left(p_{1}\right)} \Pi_{1} d p_{1}
$$

After term shifting and simplification, the last equation becomes:

$$
\frac{d p_{1}}{d \Pi_{1}}=\frac{\left(1-\rho_{1}\right) p_{1} \phi\left(p_{1}\right)}{\phi\left(p_{1}\right)-\rho_{1}\left[\phi\left(p_{1}\right)-1\right]}+\frac{1}{\Pi_{1}}+\frac{\frac{s_{1} \frac{N_{1} \bar{M}}{N_{1}+1}}{s_{1} \frac{N_{1} B\left(\Pi_{1}\right) \bar{M}}{N_{1}+1}+1}\left(1-\rho_{1}\right) p_{1} \phi\left(p_{1}\right) \frac{d B\left(\Pi_{1}\right)}{d \Pi_{1}}}{\phi\left(p_{1}\right)-\rho_{1}\left[\phi\left(p_{1}\right)-1\right]}
$$

And total differentiation of Equation (6) is as follows:

$$
\begin{aligned}
& \left(s_{1} \frac{N_{1} B\left(\Pi_{1}\right) \bar{M}}{N_{1}+1}+1\right) \psi\left(p_{1}\right)+\left(s_{1} \frac{N_{1} B\left(\Pi_{1}\right) \bar{M}}{N_{1}+1}+1\right) \Pi_{1} \psi^{\prime}\left(p_{1}\right) \frac{d p_{1}}{d \Pi_{1}}+s_{1} \frac{N_{1} \bar{M}}{N_{1}+1} \frac{d B\left(\Pi_{1}\right)}{d \Pi_{1}} \psi\left(p_{1}\right) \Pi_{1}-r s_{1} \frac{N_{1} B\left(\Pi_{1}\right) \bar{M}}{N_{1}+1}-r s_{1} \frac{N_{1} \bar{M}}{N_{1}+1} \frac{d B\left(\Pi_{1}\right)}{d \Pi_{1}} \Pi_{1} \\
& =\left(s_{1} \frac{N_{1} B\left(\Pi_{1}\right) \bar{M}}{N_{1}+1}+1\right) \psi\left(p_{1}\right)-\left(s_{1} \frac{N_{1} B\left(\Pi_{1}\right) \bar{M}}{N_{1}+1}+1\right) \frac{\phi\left(p_{1}\right)-1}{p_{1} \phi\left(p_{1}\right)} \psi\left(p_{1}\right) \Pi_{1} \frac{1-\rho_{1} p_{1} \phi\left(p_{1}\right)}{\phi\left(p_{1}\right)-\rho_{1}\left[\phi\left(p_{1}\right)-1\right]} \frac{1}{\Pi_{1}}-r s_{1} \frac{N_{1} B\left(\Pi_{1}\right) \bar{M}}{N_{1}+1} \\
& -\left(s_{1} \frac{N_{1} B\left(\Pi_{1}\right) \bar{M}}{N_{1}+1}+1\right) \frac{\phi\left(p_{1}\right)-1}{p_{1} \phi\left(p_{1}\right)} \psi\left(p_{1}\right) \Pi_{1} \frac{\frac{s_{1} \frac{N_{1} \bar{M}}{N_{1}+1}}{s_{1} \frac{N_{1} B\left(\Pi_{1}\right) \bar{M}}{N_{1}+1}+1}\left(1-\rho_{1}\right) p_{1} \phi\left(p_{1}\right) \frac{d B\left(\Pi_{1}\right)}{d \Pi_{1}}}{\phi\left(p_{1}\right)-\rho_{1}\left[\phi\left(p_{1}\right)-1\right]} \\
& +s_{1} \frac{N_{1} \bar{M}}{N_{1}+1} \frac{d B\left(\Pi_{1}\right)}{d \Pi_{1}} \psi\left(p_{1}\right) \Pi_{1}-r s_{1} \frac{N_{1} \bar{M}}{N_{1}+1} \frac{d B\left(\Pi_{1}\right)}{d \Pi_{1}} \Pi_{1} \\
& =\frac{\left(s_{1} \frac{N_{1} \bar{B} \bar{M}}{N_{1}+1}+1\right) \psi\left(p_{1}\right)}{\phi\left(p_{1}\right)\left(1-\rho_{1}\right)+\rho_{1}}-r s_{1} \frac{N_{1} B\left(\Pi_{1}\right) \bar{M}}{N_{1}+1}+s_{1} \frac{N_{1} \bar{M}}{N_{1}+1} \frac{d B\left(\Pi_{1}\right)}{d \Pi_{1}} \psi\left(p_{1}\right) \Pi_{1}\left[1-\frac{\left(1-\rho_{1}\right)\left(\phi\left(p_{1}\right)-1\right)}{\phi\left(p_{1}\right)-\rho_{1}\left[\phi\left(p_{1}\right)-1\right]}\right]-r \Pi_{1} s_{1} \frac{N_{1} \bar{M}}{N_{1}+1} \frac{d B\left(\Pi_{1}\right)}{d \Pi_{1}} \\
& =\frac{\left(s_{1} \frac{N_{1} B\left(\Pi_{1}\right) \bar{M}}{N_{1}+1}+1\right) \psi\left(p_{1}\right)}{\phi\left(p_{1}\right)\left(1-\rho_{1}\right)+\rho_{1}}-r s_{1} \frac{N_{1} B\left(\Pi_{1}\right) \bar{M}}{N_{1}+1}+s_{1} \frac{N_{1} \bar{M}}{N_{1}+1} \Pi_{1}\left[\frac{\psi\left(p_{1}\right)}{\phi\left(p_{1}\right)-\rho_{1}\left[\phi\left(p_{1}\right)-1\right]}-r\right] \frac{d B\left(\Pi_{1}\right)}{d \Pi_{1}}
\end{aligned}
$$

\section{References}

1. Levine, R. Finance and growth: Theory and evidence. In Handbook of Economic Growth; Elsevier: Amsterdam, The Netherlands, 2005; Volume 1, pp. 865-934.

2. Romer, P.M. Increasing Returns and Long-Run Growth. J. Political Econ. 1986, 94, 1002-1037. [CrossRef]

3. Ramey, G.; Ramey, V. Cross-Country Evidence on the Link between Volatility and Growth. Am. Econ. Rev. 1994, 85, 1138-1151. [CrossRef]

4. Majeed, M.T.; Noreen, A. Financial Development and Output Volatility: A Cross-Sectional Panel Data Analysis. Lahore J. Econ. 2018, 23, 97-141. [CrossRef]

5. Wang, P.; Wen, Y.; Xu, Z. Financial development and long-run volatility trends. Rev. Econ. Dyn. 2018, 28, 221-251. [CrossRef] 
6. Manganelli, S.; Popov, A. Financial development, sectoral reallocation, and volatility: International evidence. J. Int. Econ. 2015, 96, 323-337. [CrossRef]

7. Aghion, P.; Banerjee, A.; Piketty, T. Dualism and Macroeconomic Volatility. Q. J. Econ. 1999, 114, 1359-1397. [CrossRef]

8. Svirydzenka, K. Introducing a New Broad-based Index of Financial Development. 2016, Volume 16. Available online: https:/ / books.google.com.hk/books?hl=zh-CN\&lr=\&id=nrMaEAAAQBAJ\&oi=fnd\&pg=PA4\&dq=10.5089/9781513583709.00 $1 \&$ ots=pIEz3TEfr7\&sig=ApJNndc3PDR5H10wka35HibjT-8\&redir_esc=y\&hl=zh-CN\&sourceid=cndr\#v=onepage\&q\&f=false (accessed on 13 July 2021).

9. Modigliani, F. Liquidity Preference and the Theory of Interest and Money. Econometrica 1944, 12, 45. [CrossRef]

10. Friedman, M.; Schwartz, A.J. A Monetary History of the United States, 1867-1960; Princeton University Press: Princeton, NJ, USA, 1963.

11. Lucas, R.E., Jr. Expectations and currency neutrality. J. Econ. Theory 1972, 4, 103-124. [CrossRef]

12. Kydland, F.E.; Prescott, E.C. Time to Build and Aggregate Fluctuations. Econometrica 1982, 50, 1345. [CrossRef]

13. Bernanke, B.S.; Gertler, M.; Gilchrist, S. The financial accelerator in a quantitative business cycle framework. In Handbook of Macroeconomics; Elsevier: Amsterdam, The Netherlands, 1999; Volume 1, pp. 1341-1393.

14. Gertler, M.; Kiyotaki, N. Financial Intermediation and Credit Policy in Business Cycle Analysis. In Handbook of Monetary Economics; North Holland: Amsterdam, The Netherlands, 2010; Volume 3, pp. 547-599. [CrossRef]

15. Andrea, A. Financial Intermediation, Investment Dynamics, and Business Cycle Fluctuations. Am. Econ. Rev. 2016, 106, 2256-2303. [CrossRef]

16. Oliver, D.G. The financial accelerator through coordination failure. Econ. J. 2021, 131, 1620-1642. [CrossRef]

17. Arias, M.A.; Wen, Y. Does more financial development lead to more or less volatility? Reg. Econ. 2017, 25, 4-12.

18. Aghion, P.; Bacchetta, P.; Banerjee, A. Financial Development and the Instability of Open Economies. J. Monet. Econ. 2004, 51, 1077-1106. [CrossRef]

19. Ito, H.; Kawai, M. Quantity and Quality Measures of Financial Development: Implications for Macroeconomic Performance; Policy Research Institute, Ministry of Finance, Japan, Public Policy Review: Tokyo, Japan, 2018; Volume 14, pp. 803-834.

20. Bekaert, G.; Harvey, C.R.; Lundblad, C. Growth volatility and financial liberalization. J. Int. Money Financ. 2006, 25, 370-403. [CrossRef]

21. Dallas, H.; Hess, M. Financial development and stock returns: A cross-country analysis. J. Int. Money Financ. 2005, 24, 891-912. [CrossRef]

22. Easterly, W.; Islam, R.; Stiglitz, J.E. Explaining Growth Volatility; World Bank Group: Washington, DC, USA, 2000.

23. Braun, M.; Larrain, B. Finance and the Business Cycle: International, Inter-Industry Evidence. J. Financ. 2005, 60, 1097-1128. [CrossRef]

24. Raddatz, C. Liquidity needs and vulnerability to financial underdevelopment. J. Financ. Econ. 2006, 80, 677-722. [CrossRef]

25. Hadzi-Vaskov, M. Financial development, macroeconomic volatility, and economic growth. CEA J. Econ. 2011, 6, 5-34.

26. Wahid, A.N.M.; Jalil, A. Financial Development and GDP Volatility in China. Econ. Notes 2010, 39, 27-41. [CrossRef]

27. Aghion, P.; Angeletos, G.-M.; Banerjee, A.; Manova, K. Volatility and growth: Credit constraints and the composition of investment. J. Monet. Econ. 2010, 57, 246-265. [CrossRef]

28. Jungeilges, J.; Ryazanova, T. Output volatility and savings in a stochastic Goodwin economy. Eurasian Econ. Rev. 2018, 8, 355-380. [CrossRef]

29. Denizer, C.A.; Iyigun, M.F.; Owen, A.L. Finance and Macroeconomic Volatility. 2002, Volume 2. Available online: https: / / books.google.com.hk/books?hl=zh-CN\&lr=\&id=lsDI-F5sV8oC\&oi=fnd\&pg=PA23\&dq=10.2202/1534-6005.1048\&ots= 9oUUGJIeHs\&sig=4BCIsaWmDpdvx7JrEZh5UMPK5Z8\&redir_esc=y\&hl=zh-CN\&sourceid=cndr\#v=onepage\&q\&f=false (accessed on 13 July 2021).

30. Bernanke, B. The Global Saving Glut and the U.S. Current Account; Remarks at the Sandridge Lecture, Virginia Association of Economics: Virginia Beach, VA, USA, 2005.

31. Caballero, R.J.; Farhi, E.; Gourinchas, P.-O. An Equilibrium Model of “Global Imbalances" and Low Interest Rates. Am. Econ. Rev. 2008, 98, 358-393. [CrossRef]

32. Mendoza, E.G.; Quadrini, V.; Rios-Rull, J.V. Financial integration, financial development, and global imbalances. J. Political Econ. 2009, 117, 371-416. [CrossRef]

33. Tan, Z.B.; Yao, Y.; Wei, S.J. Financial structure, corporate savings, and current account imbalances. J. Int. Money Financ. 2015, 54, 142-167. [CrossRef]

34. Morawczyński, R. Venture Capitalists' Investment Criteria in Poland: Entrepreneurial Opportunities, Entrepreneurs, and Founding Teams. Adm. Sci. 2020, 10,77. [CrossRef]

35. Gambetta, N.; Azcárate-Llanes, F.; Sierra-García, L.; García-Benau, M. Financial Institutions' Risk Profile and Contribution to the Sustainable Development Goals. Sustainability 2021, 13, 7738. [CrossRef]

36. Matsuyama, K. Aggregate Implications of Credit Market Imperfections. NBER Macroecon. Annu. 2007, 22, 1-81. [CrossRef]

37. Kunieda, T.; Shibata, A. Endogenous Growth and Fluctuations in an Overlapping Generations Economy with Credit Market Imperfections. Asia Pac. J. Account. Econ. 2011, 18, 333-357. [CrossRef]

38. Zavadskas, E.K.; Turskis, Z.; Antucheviciene, J. Solution Models based on Symmetric and Asymmetric Information. Symmetry 2019, 11, 500. [CrossRef] 